\title{
Kajian Keunggulan Komparatif dan Strategi Pengembangan Kerbau Rawa Di Kalimantan Selatan
}

\section{(The Comparative Advantage and Development Strategy Assesment of Swamp Bufallo In South Kalimantan)}

\author{
Ahmad Suhaimi ${ }^{1)}$, Zarmiyeni' ${ }^{2}$, Azwar Saihani' ${ }^{3)}$, dan Rum Van Royensyah ${ }^{4)}$ \\ 1),3)\&4) Program Studi Agribisni, Sekolah Tinggi Ilmu Pertanian Amuntai \\ 1)ahmad99ec@gmail.com \\ ${ }^{2)}$ zarmiyenilg@yahoo.co.id \\ 2)Program Studi Agroteknologi, Sekolah Tinggi Ilmu Pertanian Amuntai \\ ${ }^{3)}$ Azwar.saihani63@yahoo.com \\ 4)Vanroyensyah61@gmail.com
}

\begin{abstract}
ABSTRAK
Kerbau rawa di Kalimantan Selatan merupakan komoditas potensial dalam hal penyediaan daging karena kemampuannya dapat mencerna serat kasar lebih baik dari ternak sapi dengan kondisi pakan yang memiliki kualitas rendah, dan memiliki kemampuan berkembang biak dalam rentang yang luas dari daerah basah hingga daerah relatif kering. Penelitian dilakukan di kabupaten Hulu Sungai Utara Kalimantan Selatan dengan tujuan mengkaji potensi wilayah pemeliharaan kerbau rawa, mengkaji faktor-faktor kendala dan dampak yang yang ditimbulkan dari usaha pengembangan kerbau rawa, menentukan logika keterkaitan antar masalah pengembangan kerbau rawa, menyusun Logical Framework Approach untuk pemecahan masalah (solusi) pengembangan kerbau rawa, membuat strategi yang tepat pengembangan kerbau rawa yang melibatkan peran serta dari peternak, swasta, perbankan, pemerintah daerah, serta kalangan perguruan tinggi secara berkesinambungan. Desain penelitian dengan metode deskriptif dan partisipatif dengan teknik analisis $L Q$, analisis potensi wilayah, dan Logical Framework Analysis (LFA). Hasil penelitian menunjukkan zona agroekologis rawa sangat menguntungkan untuk budidaya kerbau rawa, peran strategis penghasil daging, tenaga kerja, sumber pendapatan, penyokong sumber protein hewani, sumber bibit, daya tarik pariwisata, dan pengembangan kearifan lokal. Membandingkan antara nilai $L Q$ sebesar 2,327 dan nilai kepadatan ternak, maka Kabupaten HSU merupakan wilayah basis pengembangan ternak kerbau rawa. Model strategi pengembangan kerbau rawa di Kabupaten HSU yaitu meningkatkan penggunaan teknologi tepat guna, promosi melalui event pariwisata kerbau rawa khas Kal-Sel,, meningkatkan: peran masyarakat yang terampil, peran penyuluh dan pemerintah, meningkatkan permodalan dan hubungan kerja sama antar pelaku usaha, lokasi budidaya dekat dengan jalur transportasi, pengaturan tataguna lahan, dan memperbaiki kinerja kelembagaan.
\end{abstract}

Kata Kunci: Strategi, pengembangan, kerbau rawa, LFA.

\section{ABSTRACT}

Swamp buffalo in South Kalimantan is a potential commodity in terms of providing meat because its ability to digest crude fiber is better than cattle with low quality feed conditions, and has the ability to reproduce over a wide range from wet areas to relatively dry areas. The study was conducted in the North Hulu Sungai regency of South Kalimantan with the aim of studying the potential of swamp buffalo maintenance areas, assessing the constraints and impacts of swamp buffalo development efforts, determining the logic of the relationship between the problem of swamp buffalo development, compiling a Logical Framework Approach for problem solving (solution) the development of swamp buffalo, making the right strategy for the development of swamp buffaloes that involve the participation of farmers, the private sector, banks, local governments, and higher education institutions on an ongoing basis. Research design with descriptive and participatory methods with $L Q$ analysis techniques, analysis of regional potential, and Logical Framework Analysis (LFA). The results show that swamp agroecological zones are very beneficial for swamp buffalo cultivation, the strategic role of meat producers, labor, sources of income, advocates of sources of animal protein, sources of seeds, tourist attraction, and development of local wisdom. Comparing between the $L Q$ value of 2.327 and the value of livestock density, the HSU District is the base for developing swamp buffalo cattle. The strategy model of swamp buffalo 
development in HSU District is to increase the use of appropriate technology, promotion through typical Kal-Sel swamp buffalo tourism events, improve: the role of skilled communities, the role of extension agents and the government, increase capital and cooperative relations between business actors, locations cultivation close to transportation routes, regulating land use, and improving institutional performance.

Keywords: Strategy, development, swamp buffalo, LFA.

\section{PENDAHULUAN}

Konsumsi daging masyarakat Indonesia cenderung meningkat berbanding lurus bertambahnya jumlah penduduk, juga berkaitan dengan peningkatan pendapatan serta kesadaran pemenuhan pangan dan gizi keluarga. Kebutuhan konsumsi daging yang terus meningkat setiap tahun tanpa diimbangi dengan produksi untuk memenuhi kebutuhan tersebut, maka hampir setiap tahun terjadi kesenjangan antara tingkat produksi dengan tingkat konsumsi menyebabkan harga daging semakin meningkat. Saat ini ketersediaan daging nasional masih mengalami kekurangan yang dipenuhi melalui impor dari total kebutuhan daging nasional. Salah satu kebijakan penting untuk memenuhi ketersediaan daging adalah swasembada daging berbasis sumberdaya lokal, yaitu mengembangkan plasma nuftah kerbau rawa (Suryana dan Eko Handiwirawan, 2007).

Kalimantan Selatan mempunyai luas wilayah 3.753.052 $\mathrm{Ha}$, yang terdiri dari lahan kering $423.306 \mathrm{Ha}$, lahan pasang surut 184.099 Ha, lahan lebak 202.690 Ha, lahan tadah hujan $184.200 \mathrm{Ha}$, lahan irigasi, $63.377 \mathrm{Ha}$, dan lahan rawa $800.000 \mathrm{Ha}$. Potensi lahan tersebut baru dimanfaatkan untuk lahan pertanian berkisar 55\%. Lahan rawa masih menjadi permasalahan dalam pengembang-an usaha pertanian. Paradigma pembangunan wilayah saat ini harus mengacu pada karakteristik lokal wilayah yang dapat meningkatkan potensi wilayah tersebut dan tidak hanya sekedar memanfaatkan keunggulan komparatif, tetapi juga mengupayakan keunggulan kompetitif yang tinggi (Suryana dan Hamdan, 2010).

Kerbau rawa (swamp buffalo) di Kalimantan Selatan merupakan salah satu komoditas peternakan yang potensial dalam hal penyediaan daging karena kemampuan ternak kerbau yang dapat mencerna serat kasar yang lebih baik dari ternak sapi dengan kondisi pakan yang memiliki kualitas rendah. Kerbau dapat hidup di kawasan yang relatif sulit dalam keadaan pakan yang kurang baik. Kerbau juga memiliki kemampuan berkembang biak dalam rentang agroekosistem yang luas dari daerah yang basah hingga daerah yang relatif kering (Suryana dan Hamdan, 2010).

Kabupaten Hulu Sungai Utara merupakan salah satu daerah memiliki populasi kerbau rawa tertinggi di Kalimantan Selatan yang telah mampu beradaptasi dengan lingkungan, hal ini mendukung pengembangan ternak kebau rawa untuk memenuhi kebutuhan daging baik di tingkat daerah maupun regional sehingga angka impor daging dapat diturunkan.

Berdasarkan kondisi di atas, jika komoditi kerbau rawa ini dibudidayakan secara tepat tentu memiliki prospek yang sangat cerah guna mendukung tercapainya swasembada daging nasional. Oleh karena itu perlu dilakukan kajian potensi dan strategi pengembangan ternak lokal ini disertai penerapan pengelolaan yang inovatif agar dapat memberi kontribusi nyata pada peningkatan produksi daging lokal untuk memenuhi konsumsi pangan sumber protein, dan berguna menghadirkan informasi peluang usaha yang jelas untuk mendorong investor menanamkan modalnya.

Penelitian ini mempunyai tujuan khusus yaitu mengkaji potensi komoditas dan potensi wilayah pemeliharaan kerbau rawa, mengkaji faktor-faktor kendala dan dampak yang yang ditimbulkan dari usaha pengembangan kerbau rawa, menentukan logika keterkaitan antar masalah pengembangan kerbau rawa, menyusun Logical Framework Approach (LFA) untuk pemecahan masalah (solusi) pengembangan kerbau rawa, membuat strategi yang tepat 
untuk usaha pengembangan kerbau rawa yang melibatkan peran serta dari peternak, swasta, perbankan, pemerintah daerah, serta kalangan perguruan tinggi secara berkesinambungan.

\section{METODE PENELITIAN}

Penelitian ini dilaksanakan di Kecamatan Peminggir Kabupaten Hulu Sungai Utara Provinsi Kalimantan Selatan, mulai bulan Maret sampai dengan Oktober 2016. Besarnya populasi yang dijadikan responden dalam penelitian ini ditentukan dengan formula Slovin, dari 432 populasi diperoleh 208 responden.

Metoda penelitian digunakan adaah deskriptif dan partisipatif. Kombinasi antara analisis kuantitatif dan analisis kualitatif digunakan sebagai salah satu upaya pencarian kebenaran ilmiah lebih obyektif dengan mempertimbangkan pendekatan sosial, budaya, dan ekonomi di masyarakat.

Kajian potensi pengembangan kerbau rawa dilakukan dengan menginisiasi komoditas unggulan menggunakan metoda Location Quotient (LQ) yang diakomodasi dari Miller and Wright (1991), Isserman (1997) dan Ron Hood (1998) dan dilanjutkan dengan analisis potensi pengembangan wilayah menurut Sumanto dan Juarini (2004).

Kajian strategi pengembangan kerbau rawa menggunakan Metode Partisipatif dengan teknik Analisis Kerangka Logika (Logical Framework Analysis, LFA). Pendekatan ini disusun dengan tujuan meningkatkan sistematika perencanaan dan perkembangan sesuatu kegiatan. Sebagai salah satu alat (tools) yang digunakan untuk pencapaian tujuan terstruktur (Norad, 1999). Di dalamnya memuat analisis para pihak (stakeholder analysis), analisis SWOT (SWOT analysis), analisis pohon masalah (problem tree analysis), analisis tujuan (objectives hierarchy analysis).

\section{HASIL DAN PEMBAHASAN}

\section{Potensi dan Daya Dukung Pengembangan Kerbau Rawa}

\section{Keunggulan Komparatif Kerbau Rawa}

Tabel 1. Nilai LQ Kerbau Rawa di Kabupaten HSU, Provinsi Kal-Sel

\begin{tabular}{ccc}
\hline Kabupaten & Nilai LQ & Kategori \\
\hline Hulu Sungai Utara & 2,327 & Basis Wilayah Surplus \\
\hline
\end{tabular}

LQ>1, menunjukkan wilayah telah memiliki keunggulan komparatif, dimana populasinya melebihi kebutuhan di daerahnya sehingga kelebihan produk bisa dijual atau diekspor ke luar wilayah. Strategi yang tepat untuk wilayah surplus ini adalah meningkatkan pembinaan perbaikan manajemen pemeliharaan ternak, pembangunan kandang yang baik dan hygenis, pembangunan sentra pemasaran ternak, dan optimalisasi penerapan teknologi pakan melalui pemberdayaan masyarakat pola partisipatif.

\section{Kepadatan Ternak}

Kriteria kepadatan ekonomi ternak dengan nilai 1.125 yaitu sangat padat menunjukkan adanya kemungkinan terjadi kompetisi, dimana jumlah penduduk akan menjadi pesaing bagi keberadaan ternak dalam hal penyediaan makanan.

Tabel 2. Kepadatan Ternak Kerbau Rawa di Kabupaten HSU, Tahun 2016

\begin{tabular}{|c|c|c|c|c|c|c|}
\hline \multirow{3}{*}{ Kecamatan } & \multicolumn{4}{|c|}{ Kepadatan Ternak } & \multirow{2}{*}{\multicolumn{2}{|c|}{ Wilayah }} \\
\hline & & konomi & Usah & Tani & & \\
\hline & $\mathrm{N}$ & $\mathrm{K}$ & $\mathrm{N}$ & K & $\mathrm{N}$ & $\mathrm{K}$ \\
\hline Paminggir & 1.125 & Sangat Padat & 1,661 & Padat & 56,971 & Sangat Padat \\
\hline
\end{tabular}


ini kurang mampu lagi untuk mendukung usaha pengembangan ternak kerbau rawa. Sehingga usaha yang dilakukan adalah memanfaatkan pakan di padang penggembalaan lebih intensif, dan meningkatkan pengetahuan peternak dalam hal pengolahan pakan kerbau rawa.

Nilai kepadatan wilayah adalah 56,971 dengan kategori sangat padat, menunjukkan wilayah ini kurang memungkinkan untuk dilakukan penambahan sejumlah ternak kerbau rawa, sehingga usaha yang dapat dilakukan adalah meningkatkan pembinaan perbaikan manajemen pemeliharaan dan produktivitas ternak.

Membandingkan nilai LQ ternak kerbau rawa dan nilai kepadatan ternak kerbau rawa di wilayah Kecamatan Paminggir Kabupaten HSU, dapat disimpulkan bahwa Kecamatan Paminggir merupakan wilayah basis pengembangan ternak kerbau rawa yang didukung oleh potensi lahan rawa yang menyediakan makanan hijauan ternak, keterampilan SDM peternak turun-temurun. Wilayah basis pengembangan ternak kerbau di wilayah ini diindikasikan dengan populasi yang optimal yang ditandai dengan kategori ternak yang padat, baik kepadatan ekonomi, kepadatan usaha tani, dan kepadatan wilayah.

\section{Strategi Pengembangan Usaha Kerbau Rawa}

\section{Stakeholder Analysis}

Pihak-pihak yang berperan sebagai stakeholder dalam usaha pengembangan ternak kerbau rawa di Kabupaten Hulu Sungai Utara yaitu peternak kerbau rawa, investor, industri, bank, kelompok ternak kerbau rawa, dan perguruan tinggi. Adanya jalinan kemitraan yang saling mendukung dan menguntungkan antar pihak.

\section{SWOT Analysis}

Tabel 3. Matriks SWOT Pengembangan Agribisnis Kerbau Rawa di Kabupaten Hulu Sungai Utara.

\begin{tabular}{|c|c|c|}
\hline Eksternal & $\begin{array}{l}\text { Kekuatan (S) } \\
\text { 1. Wilayah yang luas untuk } \\
\text { kegiatan usaha ternak kerbau } \\
\text { rawa } \\
\text { 2. Perubahan iklim tidak } \\
\text { mempengaruhi } \quad \text { proses } \\
\text { pemeliharaan ternak kerbau rawa } \\
\text { 3. Menjadikan usaha utama pemilik } \\
\text { 4. Adanya regenerasi usaha } \\
\text { peternakan (turun temurun) } \\
\text { 5. Terampil dan berpengalaman } \\
\text { 6. Pemasaran yang mudah }\end{array}$ & $\begin{array}{l}\text { Kelemahan (W) } \\
\text { 1. Ketersediaan Hijauan Pakan } \\
\text { Ternak Sangat Dipengaruhi } \\
\text { Oleh Musim } \\
\text { 2. Sistem usaha tani masih } \\
\text { sederhana dan tradisional } \\
\text { 3. Kurang Optimalnya } \\
\text { Kelembagaan } \\
\text { 4. Kurangnya keahlian di dalam } \\
\text { penanganan hasil } \\
\text { 5. Modal terbatas, hanya } \\
\text { menggunakan modal sendiri } \\
\text { 6. Kematian Anak Relatif Tinggi }\end{array}$ \\
\hline $\begin{array}{l}\text { Peluang }(\mathrm{O}) \\
\text { 1. Permintaan daging meningkat } \\
\text { 2. Pengembangan Objek Wisata } \\
\text { 3. Peluang Kerja Masyarakat } \\
\text { 4. Perkembangan Teknologi Yang } \\
\text { Semakin Maju }\end{array}$ & $\begin{array}{l}\text { Strategi S-O } \\
\text { 1. Meningkatkan penggunaan } \\
\text { teknologi tepat guna pemeliharaan } \\
\text { ternak } \\
\text { 2. Event lomba pacuan kerbau rawa } \\
\text { 3. Meningkatkan peran masyarakat } \\
\text { yang terampil, penyuluh, } \\
\text { pemerintah, dan PT agar usaha } \\
\text { ternak dapat kontinu }\end{array}$ & $\begin{array}{l}\text { Strategi W-O } \\
\text { 1. Pembinaan/penyuluhan dari } \\
\text { instansi terkait yang lebih } \\
\text { intensif dalam hal budidayadan } \\
\text { kelembagaan. } \\
\text { 2. Meningkatkan permodalan untuk } \\
\text { membantu dalam pengembangan } \\
\text { usaha. }\end{array}$ \\
\hline $\begin{array}{l}\text { Ancaman }(\mathrm{T}) \\
\text { 1. Adanya perubahan tataguna lahan } \\
\text { akibat perluasan areal tanam } \\
\text { 2. Masih rawan pencurian kerbau } \\
\text { rawa } \\
\text { 3. Kenaikan harga BBM } \\
\text { 4. Permintaan kerbau fluktuatif } \\
\end{array}$ & $\begin{array}{l}\text { Strategi S-T } \\
\text { 1. Meningkatkan kemitraan antar } \\
\text { pelaku usaha. } \\
\text { 2. Lokasi kalang dibuat dekat } \\
\text { dengan jalur transportasi }\end{array}$ & $\begin{array}{l}\text { Strategi W-T } \\
\text { 1. Optimalisasi tataguna } \\
\text { peternakan dengan baik } \\
\text { 2. Penguatan kapasitas } \\
\text { kelembagaan }\end{array}$ \\
\hline
\end{tabular}


Ada 3 kelompok utama yang menjadi penyebab kurang berkembangnya usaha kerbau rawa di kecamatan Paminggir yaitu berkurangnya pakan ternak di alam, keterbatasan modal usaha dan tidak adanya penyuluh peternakan dan dokter hewan yang ditugaskan di desa Sapala,

\section{Objectives hierarchy analysis}

Pengembangan usaha ternak kerbau rawa di kabupaten Hulu Sungai Utara yang terpadu dan terencana sehingga pemecahan masalah dapat teratasi dengan tepat dan cepat yaitu dengan kemudahan peminjaman modal usaha, memenuhi permintaan kerbau rawa yang meningkat, tersedia sarana dan prasarana (dermaga), terjaminnya mutu peralatan atau fasilitas pembibitan, penguatan kapasitas kelompok usaha, SDM peternak terampil, peternak mampu mengadopsi teknologi budidaya, ketersediaan ahli teknologi budidaya, adanya informasi kondisi wilayah, pemanfaatan areal budidaya secara optimal

\section{Bagan Keterkaitan Masalah}

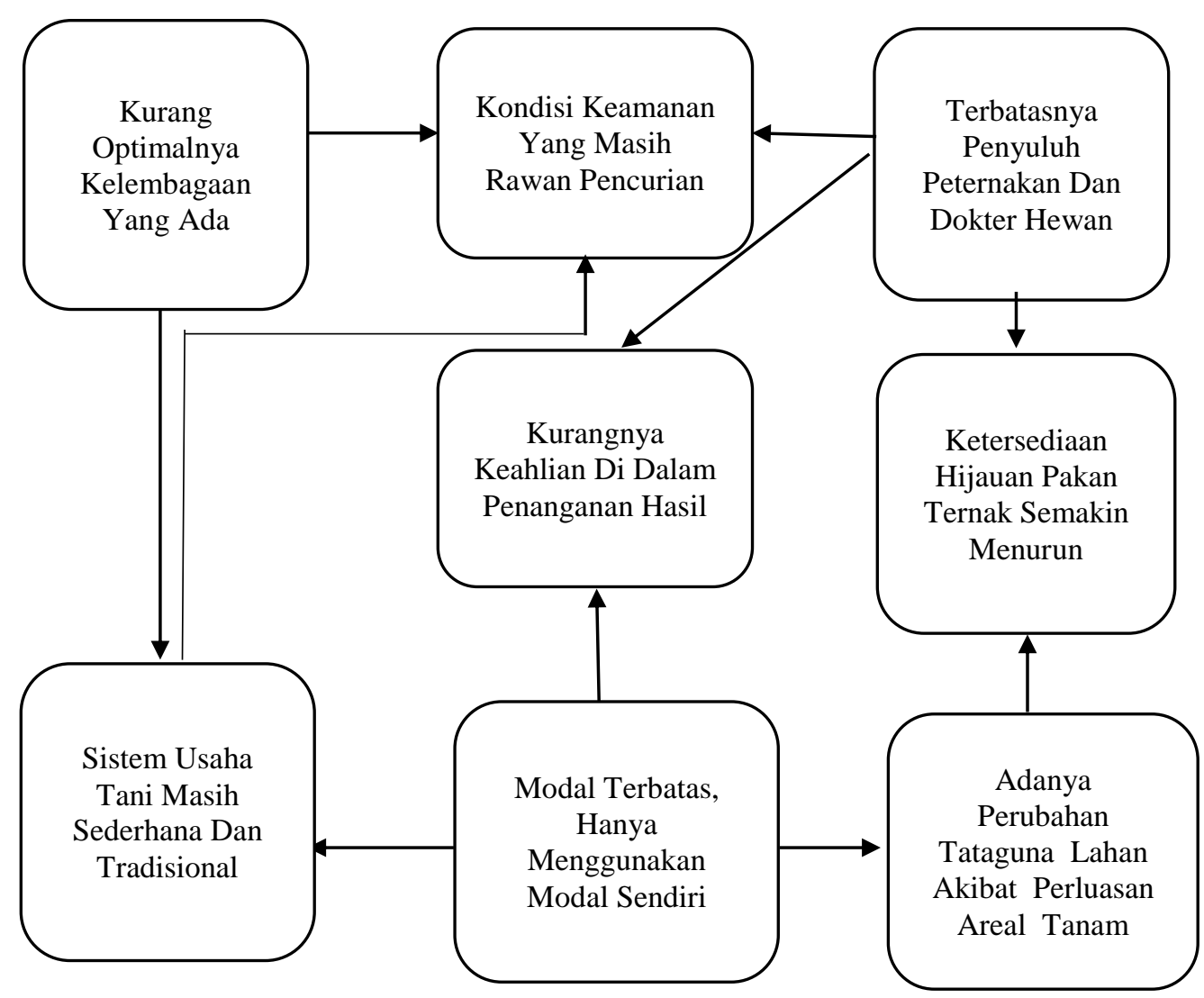

Gambar 1. Keterkaitan permasalah pengembangan usaha kerbau rawa di Kecamatan Paminggir Kabupaten Hulu Sungai Utara 


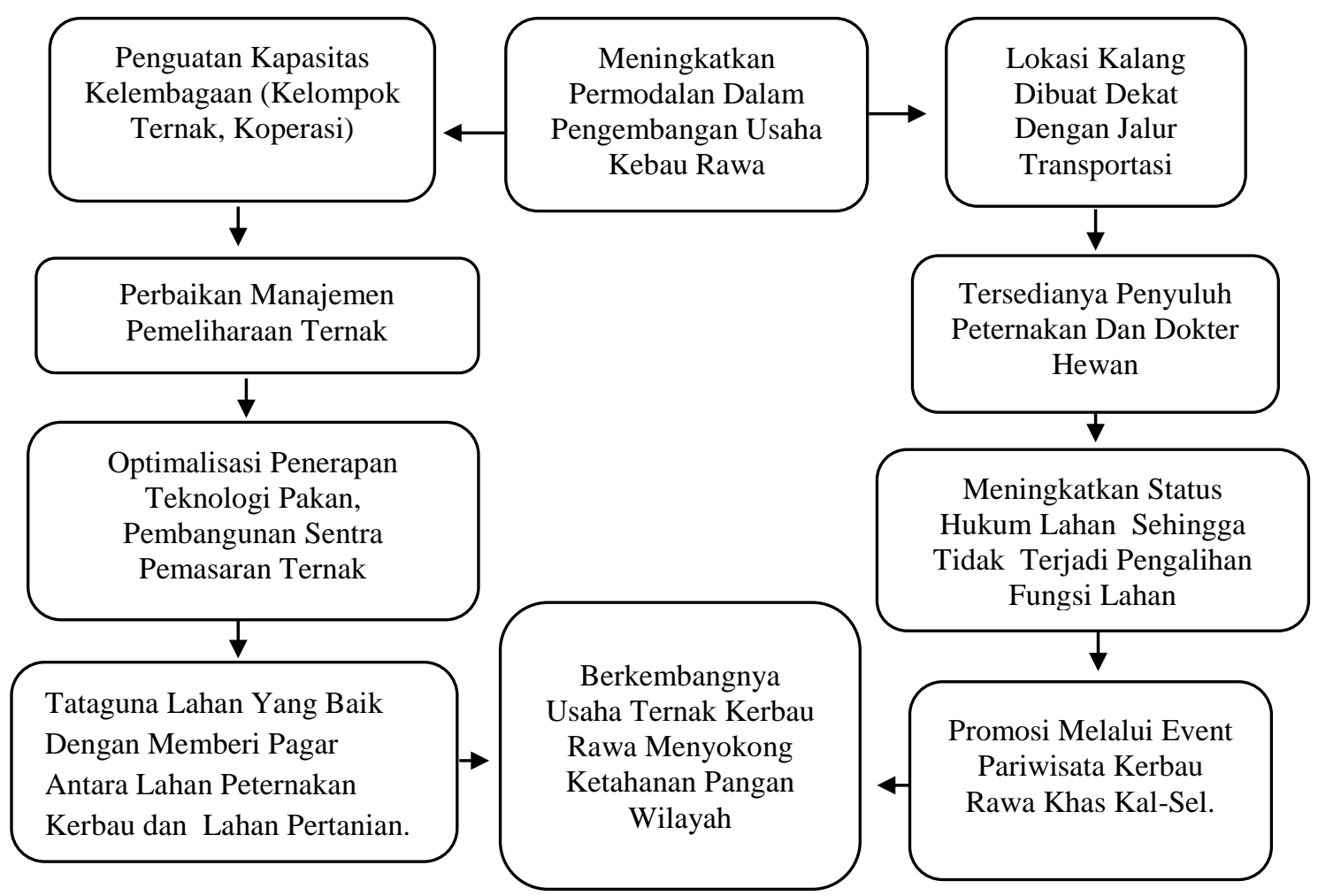

Hasil Logical Framework Analysis (LFA)

Gambar 2. Keterkaitan strategi pengembangan usaha kerbau rawa di Kecamatan Paminggir Kabupaten Hulu Sungai Utara

\section{KESIMPULAN}

Model strategi pengembangan kerbau rawa di $\mathrm{K}=$ abupaten Hulu Sungai Utara yaitu meningkatkan penggunaan teknologi tepat guna, mengadakan lomba pacuan kerbau rawa, meningkatkan peran serta masyarakat yang terampil, peran penyuluh dan pemerintah, pembinaan/penyuluhan dari instansi terkait, meningkatkan permodalan, meningkatkan hubungan kerja sama antar pelaku usaha, lokasi kalang dibuat dekat dengan jalur transportasi, serta meningkatkan tataguna lahan peternakan dengan baik, dan memperbaiki kinerja kelembagaan.

\section{UCAPAN TERIMA KASIH}

Kemenristikdikti dan Dinas Peternakan Kabupaten Hulu Sungai Utara Provinsi Kalimantan Selatan.

DAFTAR PUSTAKA
Isserman, Andrew.M. 1997. The Location Quotient Approach for Estimating Regional Economic Impacts. AIP Journal Miller.

M..M, J.L.Gibson, \& G.N. Wright .1991. Location Quotient Basic Tool for Economic Development Analysis. Economic Development Review. 9(2);65

NORAD. 1999. The Logical Framework Approach (LFA); Handbook for Objectives-Oriented Planning Fourth Edition. Norway: NORAD

Sumanto dan Juarini E. 2004. Potensi kesesuaian lahan untuk pengembangan ternak ruminansia di Propinsi Nusa Tenggara Timur. Prosiding. Seminar Nasional Teknologi Peternakan dan Veteriner, Iptek sebagai Motor Penggerak Pembangunan Sistem dan Usaha Agribisnis 
Peternakan. Bogor 4-5 Agustus 2004. Bogor. Puslitbangnak.

Suryana dan Eko Handiwirawan. 2007. Daya dukung lahan rawa sebagai kawasan sentra pengembangan kerbau kalang Di Kalimantan Selatan. Seminar Nasional dan Lokakarya Usahaternak Kerbau. Balai Pengkajian Teknologi Pertanian Kalimantan Selatan dan Pusat Penelitian dan Pengembangan Peternakan.
Suryana dan Hamdan. 2010. Potensi lahan rawa Di Kalimantan Selatan untuk pengembangan peternakan kerbau. Lokakarya Nasional Usaha Ternak Kerbau Mendukung Program Kecukupan Daging Sapi. Balai Pengkajian Teknologi Pertanian Kalimantan Selatan.

Ron Hood. 1998. Economic Analysis: A Location Quotient. Primer. Principal Sun Region Associates, Inc. 